\title{
Habitats Used by Juvenile Flagtails (Kublia spp.; Perciformes: Kuhliidae) on the Island of Hawai ${ }^{\circ}{ }^{1}$
}

\author{
Mark G. McRae, ${ }^{2}$ Lori Benson McRae, ${ }^{2,3}$ and F. Michael Fitzsimons ${ }^{4}$
}

\begin{abstract}
Patterns of juvenile habitat use by two species of kuhliid fishes (āholehole) on the island of Hawai' $i$ were examined. Kublia sandvicensis was observed in marine habitat types only, but juvenile K. xenura were observed in freshwater streams, estuaries, on reef flats, along rocky shorelines, and in tide-pool habitats. Principal components analysis indentified nonrandom microhabitat selection by juvenile $K$. sandvicensis and $K$. xenura. Both species selected microhabitats that were higher in salinity and temperature and nearer to the open ocean than were areas randomly available to them. Although distributions of juvenile $K$. sandvicensis and $K$. xenura overlapped in marine habitats, characteristics of the marine microhabitats used by each species differed. Along rocky shorelines, K. sandvicensis used microhabitats that were characteristic of high-energy surge zonesdeep areas close to the open ocean that had high salinities. The rocky shorelines most frequently inhabited by $K$. xenura, conversely, were shallower areas that were farther from the open ocean with lower salinity. A similar pattern was observed in tide-pool habitats, with $K$. sandvicensis using microhabitats typical of surge zones, and K. xenura utilizing protected tide pools with low salinities. Protection of a variety of inshore habitats is important for conservation of juvenile Hawaiian kuhliid fishes.
\end{abstract}

Fishes IN THE genus Kublia (the "flagtails") are found throughout the Indo-Pacific in marine, estuarine, and freshwater habitats. Known in Hawai'i as āholehole, they are highly sought-after food fishes and represent an important fishery. Āholehole were also culturally important to the ancient Hawaiian people and were often used in religious ceremonies (Titcomb 1972). Although two morphotypes (based primarily on eye size) had long been noted by local fishermen and biolo-

\footnotetext{
${ }^{1}$ Funding was provided by the Hawai'i Division of Aquatic Resources and the University of Tampa. Manuscript accepted 4 February 2011.

${ }^{2}$ University of Tampa, Department of Biology, 401 West Kennedy Boulevard, Tampa, Florida 33606.

${ }^{3}$ Corresponding author (phone: 813-257-3941; fax: 813-258-7891; e-mail: lmcrae@ut.edu).

${ }^{4} 4334$ DeBellevue Drive, Baton Rouge, Louisiana 70809 .
}

Pacific Science (2011), vol. 65, no. 4:441-450

doi: $10.2984 / 65.4 .441$

(C) 2011 by University of Hawai'i Press

All rights reserved gists, before 2001 only one species, Kublia sandvicensis (Steindachner, 1876), was recognized in the scientific literature (Tester and Takata 1952, Gosline and Brock 1965, Tinker 1978, Randall 1985, 1996, Witte and Mahaney 1998). Randall and Randall (2001) published a revision of the genus that, based on meristic analysis, effectively "split" $K$. sandvicensis into two species. The "big-eyed" (colloquial) morphotype was assigned the available name $K$. xenura (Jordan \& Gilbert, 1882), and this species is now believed to be endemic to the Hawaiian Islands. Meanwhile, the "small-eyed" morphotype, even though less frequently observed in what were formerly known as the Sandwich Islands, retained the name $K$. sandvicensis. Morphometric and genetic analyses of the two morphotypes provided confirmation that two species of Kublia occur in Hawaiian waters (McRae 2007). Although superficially similar, consistently observable differences in appearance exist between these two species. For example, the big-eyed K. xenura (or Hawaiian Flagtail) is deeper bodied and has finer and lessconspicuous reticulations on the head and 

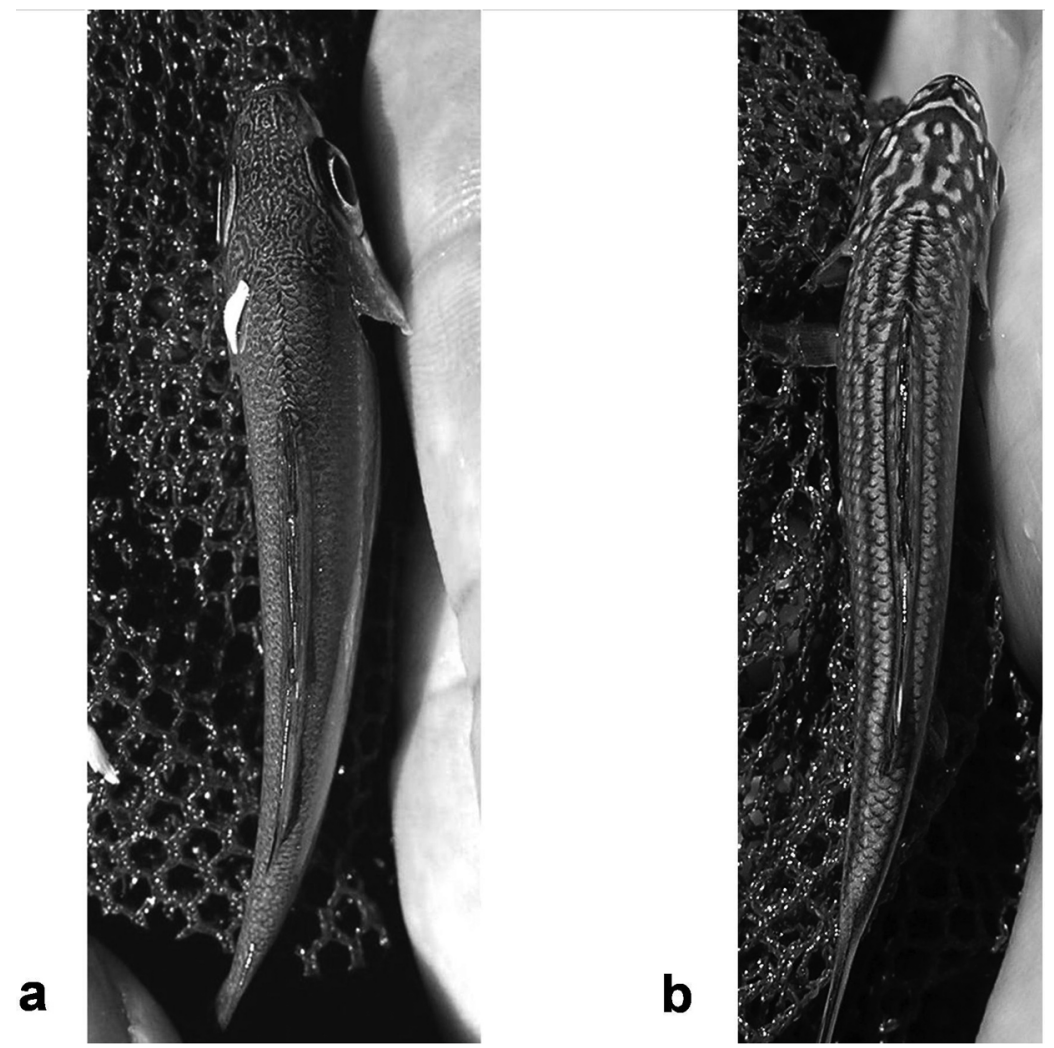

FIgURE 1. Vermiculated pattern on the dorsal surface of (a) Kublia xenura and (b) Kublia sandvicensis (from McRae 2007).

dorsal surface compared with the small-eyed $K$. sandvicensis (hence the common name Zebra-head Flagtail) (Figure 1).

It is not known whether information on the ecology and behavior of Hawaiian Kublia obtained before Randall and Randall's (2001) taxonomic revision (e.g., Tester and Takata 1953, Gosline 1965, Hosaka 1973) included observations on $K$. sandvicensis, $K$. xenura, or both species. Juvenile $K$. xenura have been documented to use riffles and runs in the terminal reach of Wailoa Stream on the island of Hawai'i as juvenile habitat (M.G.M., unpubl. data). Strontium/calcium profiles in the otoliths of $K$. sandvicensis and $K$. xenura indicated that both species experienced exposure to full-strength seawater and to water of reduced salinity during the life of individual animals (Benson and Fitzsimons 2002). To date, how- ever, detailed analyses of the ecological similarities and differences between these two species are lacking.

The goal of this study was to compare both macro- and microhabitat use by juveniles of both kuhliids in Hawai'i to gain insight into the spatial ecology of these commercially and recreationally important species. The critical role of juvenile habitats in the survival and recovery of fish populations around the world has been well established (e.g., Rozas and Hackney 1983, Jennings 1992, Whitfield 1997, Desmond et al. 2000, Hendon et al. 2001). To obtain crucial ecological information that may aid in the management of aholehole in the Hawaiian Islands, the following null hypotheses were tested: (1) juvenile $K$. sandvicensis and $K$. xenura were utilizing the same habitat types (e.g., tide pools, streams, 


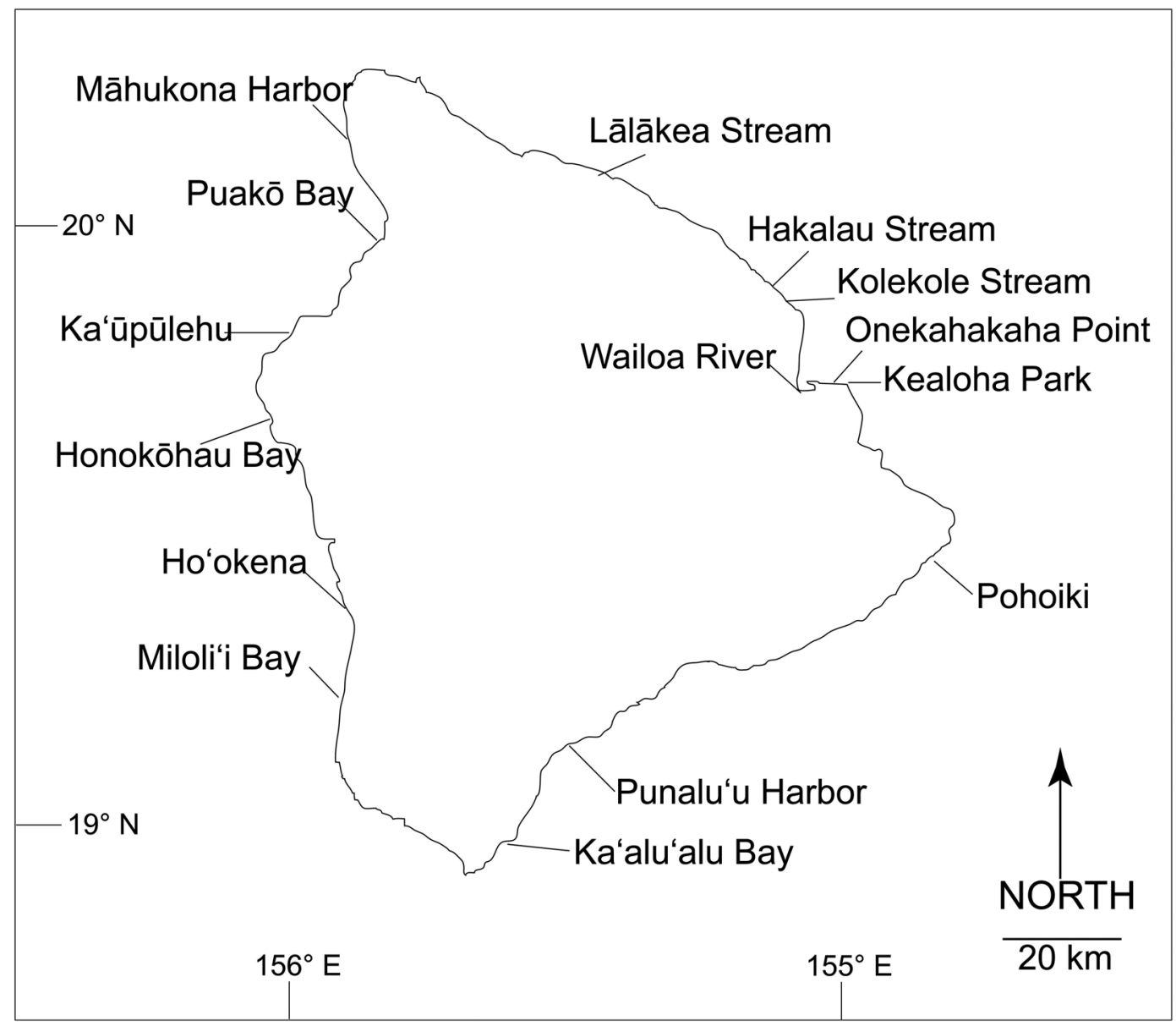

Figure 2. Survey sites on the island of Hawai'i.

etc.) on the island of Hawai' $\mathrm{i}$; (2) the microhabitats utilized by $K$. sandvicensis and $K . x e-$ nura on the island of Hawai'i were not significantly different from the range of microhabitat conditions that were randomly available to them; and (3) in habitat types where both species occurred together, no partitioning of spatial resources was taking place.

\section{MATERIALS AND METHODS}

\section{Field Methods}

Study sites were located along all coastlines of the island of Hawai' $i$ and were selected based on accessibility and because they encompassed all the freshwater, estuarine, and marine habitat types in which juvenile Kublia have been observed in Hawai'i (Figure 2). Marine habitat types surveyed included rocky shorelines, tide pools, and reef flats. Estuarine habitat types consisted of mixohaline terminal stream reaches and a brackish-water fishpond. Stream reaches far enough inland to not be influenced by tidal influx of salt water were the only freshwater habitats surveyed. Fish habitat use and random habitat availability data were collected during January, March, and May of 2004. A random numbers table was used to select the starting points of surveys 
near shoreline or stream access points. While facing the water at the shoreline (or stream bank), the farthest visible point on the shoreline to the left was designated as $0 \%$, and the farthest visible point to the right was designated as $100 \%$. A random number of 65 , for example, would result in a survey that started at a point that was located approximately $65 \%$ between the two farthest visible points. Surveys included all areas containing potential habitats along a 50-100 m length of shoreline (or stream reach) to the right or left of the randomly located starting point. Survey direction alternated between surveys. Fish were located visually either from the surface by using polarized glasses or during underwater snorkel surveys. All juvenile Kublia located were identified to species, counted, and their fork lengths (FL) were estimated. Kublia were considered to be juveniles if they were less than $15 \mathrm{~cm}$ FL (Tester and Takata 1953). The exact location of each individual or group of undisturbed Kublia was marked with a flagged fishing weight. Although the two species could be distinguished visually, fish were collected periodically to verify species identifications and length estimates.

The habitat type in which fish were observed was recorded (stream, estuary, rocky shoreline, tide pool, or reef flat), and the distance from the open ocean (as indicated by observable wave surge) was either measured by using a $100 \mathrm{~m}$ tape measure or visually estimated. For survey sites located in stream reaches, the distance from the open ocean was estimated by using a topographical map and a digital map wheel (Scalex). At each marked fish location, salinity, temperature, and dissolved oxygen were measured with a multiprobe (YSI). Depth and mean water column velocity were measured using a top-set wading rod and an electromagnetic flow meter (Marsh-McBirney Flo-Mate 2000). To characterize microhabitat availability at each study site, a random number table was used to select 30-50 points within the survey area. At each of these random points, measurements were made on the same set of variables that were measured for the marked fish locations. The total area of each habitat type surveyed was estimated by subdividing each surveyed habi- tat into rectangular and triangular sections, and using a $100 \mathrm{~m}$ tape measure to measure the length and width of each subsection.

\section{Statistical Analysis}

SYSTAT 8.0 (SPSS Inc. 1998) was used to perform all statistical tests. To examine whether or not the juveniles of the two species of Kublia were utilizing the same habitat types on the island of Hawai' $i$, population densities for each species were calculated for each habitat type. For each survey site, the total number of fish observed in each habitat type was divided by the total area (square meters) of that habitat type present. Mann-Whitney $U$ tests (nonparametric analog of the two-sample $t$-test) were performed to test for significant differences between the mean population densities (number $\cdot \mathrm{m}^{-1}$ ) of the two species in each habitat type.

To test for nonrandom microhabitat selection by $K$. sandvicensis and $K$. xenura, a Principal Components Analysis (PCA) was conducted on the random availability data. Before running the PCA, data for variables that displayed excessive skewness or kurtosis were transformed as necessary with either a square root or a fourth root transformation. The PCA (based on the correlation matrix with a Varimax rotation) extracted independent component axes that described patterns of microhabitat variation within surveyed habitats. Observations of fish microhabitat use were scored and superimposed on the component axes by multiplying each fish's microhabitat use data by the eigenvectors associated with the microhabitat variables on each component axis (Grossman and Freeman 1987). Two-sample Kolmogorov-Smirnoff (KS) tests were used to examine whether or not the frequency distribution of each species' principal component scores were significantly different in shape from those of the habitat availability scores.

To test for interspecific differences in microhabitat use in habitat types where they occurred together, the mean values of microhabitat variables observed for both species were compared by using Mann-Whitney $U$ tests. 


\section{RESULTS}

A total of 152 juvenile $K$. sandvicensis (15-82 $\mathrm{mm}$ FL) and 707 juvenile K. xenura (12-123 $\mathrm{mm}$ FL) was observed. Juvenile $K$. xenura were found in every habitat type surveyed. Although $K$. xenura was more commonly encountered in most habitat types surveyed, their densities were not significantly higher than those observed for $K$. sandvicensis except for in streams and estuaries, where $K$. sandvicensis was not observed (Table 1). MannWhitney $U$-tests for differences between the population densities of the two species were, consequently, significant at the $\alpha=.05$ level for the stream $(U=2.5, P=.02)$ and estuary $(U=0, P=.01)$ habitat types only (Table 1$)$. The first null hypothesis, which stated that juvenile $K$. sandvicensis and $K$. xenura were utilizing the same habitat types on the island of Hawai' $i$ was therefore rejected.

Our second null hypothesis, stating that the microhabitats utilized by $K$. sandvicensis and $K$. xenura on the island of Hawai' $i$ were not significantly different from the range of microhabitat conditions that were randomly available to them, was also rejected. The PCA performed on the microhabitat availability

\section{TABLE 1}

Total Area of Each Habitat Type Surveyed, with Associated Population Densities and Site Information, Sample Sizes (Number of Individual Survey Sites in Each Habitat Type), Mann-Whitney Test Statistic (U), and Associated $P$-Values

\begin{tabular}{|c|c|c|c|c|}
\hline \multirow[b]{2}{*}{ Habitat $\left(\mathrm{m}^{2}\right)$} & \multirow[b]{2}{*}{ Site $\left(\mathrm{m}^{2}\right)$} & \multicolumn{2}{|c|}{ No. per $\mathrm{m}^{2} \pm$ Standard Error } & \multirow[b]{2}{*}{$n, U, p$-Value } \\
\hline & & K. xепura & K. sandvicensis & \\
\hline Stream $(1,054)$ & $\begin{array}{l}\text { Hakalau (88) } \\
\text { Kolekole (50) } \\
\text { Lālākea (916) }\end{array}$ & $0.27 \pm 0.17$ & 0 & $5,2.5, .02^{*}$ \\
\hline Estuary (219) & $\begin{array}{l}\text { Hakalau (70) } \\
\text { Kolekole (60) } \\
\text { Wailoa River (89) }\end{array}$ & $0.44 \pm 0.14$ & 0 & $4,0, .01^{*}$ \\
\hline Reef flat $(4,156)$ & $\begin{array}{l}\text { Honokōhau Bay }(2,517) \\
\text { Ho'okena }(871) \\
\text { Ka'ūpūlehu }(396) \\
\text { Miloli'i Bay }(75) \\
\text { Puakō Bay (296) }\end{array}$ & $0.02 \pm 0.01$ & $0.01 \pm 0.004$ & $5,9, .45$ \\
\hline Rocky shoreline $(1,717)$ & $\begin{array}{l}\text { Ka'alu'alu Bay (594) } \\
\text { Ka'ūpūlehu (30) } \\
\text { Kealoha (131) } \\
\text { Māhukona Harbor (144) } \\
\text { Miloli'i Bay (34) } \\
\text { Onekahakaha Point (484) } \\
\text { Pohoiki (217) } \\
\text { Puakō Bay (45) } \\
\text { Punalu'u Harbor (38) }\end{array}$ & $0.11 \pm 0.07$ & $0.16 \pm 0.16$ & $11,77, .19$ \\
\hline Tide pool $(1,194)$ & $\begin{array}{l}\text { Honokōhau Bay (3) } \\
\text { Ho'okena (11) } \\
\text { Ka'alu'alu Bay (15) } \\
\text { Ka'ūpūlehu (99) } \\
\text { Māhukona Harbor (16) } \\
\text { Miloli'i Bay (496) } \\
\text { Onekahakaha Point (146) } \\
\text { Pohoiki (30) } \\
\text { Puakō Bay (338) } \\
\text { Punalu'u Harbor (41) }\end{array}$ & $1.77 \pm 1.52$ & $0.2 \pm 0.11$ & $13,61, .21$ \\
\hline
\end{tabular}

\footnotetext{
a An asterisk $\left(^{*}\right)$ identifies comparisons where the densities of the two species in a particular habitat type were significantly different.
} 
TABLE 2

Rotated Loading Values for Microhabitat Variables on Each Principal Component (PC) Axis

\begin{tabular}{lrr}
\hline \hline Microhabitat Variable & PC1 & PC2 \\
\hline Temperature & -0.84 & -0.30 \\
Dissolved oxygen & 0.31 & -0.77 \\
Salinity & -0.89 & 0.12 \\
Distance to open ocean & 0.71 & -0.16 \\
Mean water column velocity & -0.05 & 0.79 \\
Depth at fish & 0.17 & 0.45 \\
\hline
\end{tabular}

data $(n=172)$ produced two component axes that explained $61.4 \%$ of the total variance in the data set. Microhabitat variables with high loading values on Principal Component (PC) axis 1 were temperature, salinity, and distance to the open ocean; dissolved oxygen, mean water column velocity, and depth at fish had high loading values on PC axis 2 (Table 2, Figure 3$)$. Juvenile $K$. sandvicensis $(n=152)$ showed strongly nonrandom microhabitat use on $\mathrm{PC}$ axis $1(P<.0005$ [Figure 3]): they selected microhabitats that were higher in salinity and temperature, and closer to the open ocean than were randomly available (Table 3, $\mathrm{g}$ and $\mathrm{h})$. Kublia sandvicensis juveniles also displayed nonrandom $(P<.0005)$ microhabitat use with respect to PC axis 2 (Figure 3). They utilized relatively deep areas with lower levels of dissolved oxygen and lower water velocity than were randomly available on the island of Hawai'i (Figure 3; Table 3, g and h). Kublia xenura juveniles showed nonrandom microhabitat use on $\mathrm{PC}$ axis $1(P<.0005)$ but not on $\mathrm{PC}$ axis $2(P=.16$ [Figure 3]). Juvenile $K$. xenura selected microhabitats that were higher in salinity and temperature, and closer to the open ocean than were randomly available (Figure 3; Table 3, g and h). The distributions of principal component scores for $K$. xenura on PC axis 2 were not significantly different from the distribution of scores for random microhabitat availability $(P=.16$ [Figure 3]).

Finally, the third null hypothesis, which stated that no microhabitat partitioning was taking place between juveniles of the two species in habitat types where they co-occur, was rejected. In marine sites, the use of microhab- itats differed between $K$. sandvicensis and $K$. xenura (Table 3, f). Kublia sandvicensis generally used marine microhabitats that were lower in dissolved oxygen, of higher salinity, located nearer to the open ocean, and higher in water velocity than were the microhabitats used by K. xenura (Table 3, f). Mann-Whitney $U$-tests indicated significant differences between the two species with respect to the means of the microhabitat observations measured along rocky shorelines (except for mean water column velocity) and in tide pools (except for temperature and depth at fish) but not on reef flats (except for dissolved oxygen [Table 3, c-e]).

\section{DISCUSSION}

The results presented here indicate that $K$. sandvicensis utilized a narrower range of habitats during the juvenile stage than $\operatorname{did} K$. xenura. The most notable results were that juvenile $K$. sandvicensis were only observed in marine habitat types and were never observed at the estuary sites or in freshwater streams during this study. Juvenile $K$. xenura, conversely, were found in every marine, estuarine, and freshwater habitat surveyed. In marine habitat types where the two species occurred together, $K$. xenura generally used areas that were farther from the open ocean than did K. sandvicensis. During this study, it was not uncommon to observe schools of juvenile $K$. xenura inhabiting the most protected areas of rocky shorelines, while juvenile K. sandvicensis were observed in the turbulent surge zones along the same shorelines. A similar pattern was observed in tide pools where the two species overlapped in their distributions. In tide-pool habitats, juvenile K. sandvicensis were commonly observed within or very near high-energy surge zones that were higher in salinity and water velocity. Conversely, the areas of tide pools inhabited by $K$. xenura were brackish and protected from wave surge such that water velocities were low.

The habitat-use patterns described here for Hawai'i's kuhliid fishes correspond to broader patterns in their biogeography. Kublia sandvicensis has been recorded from 

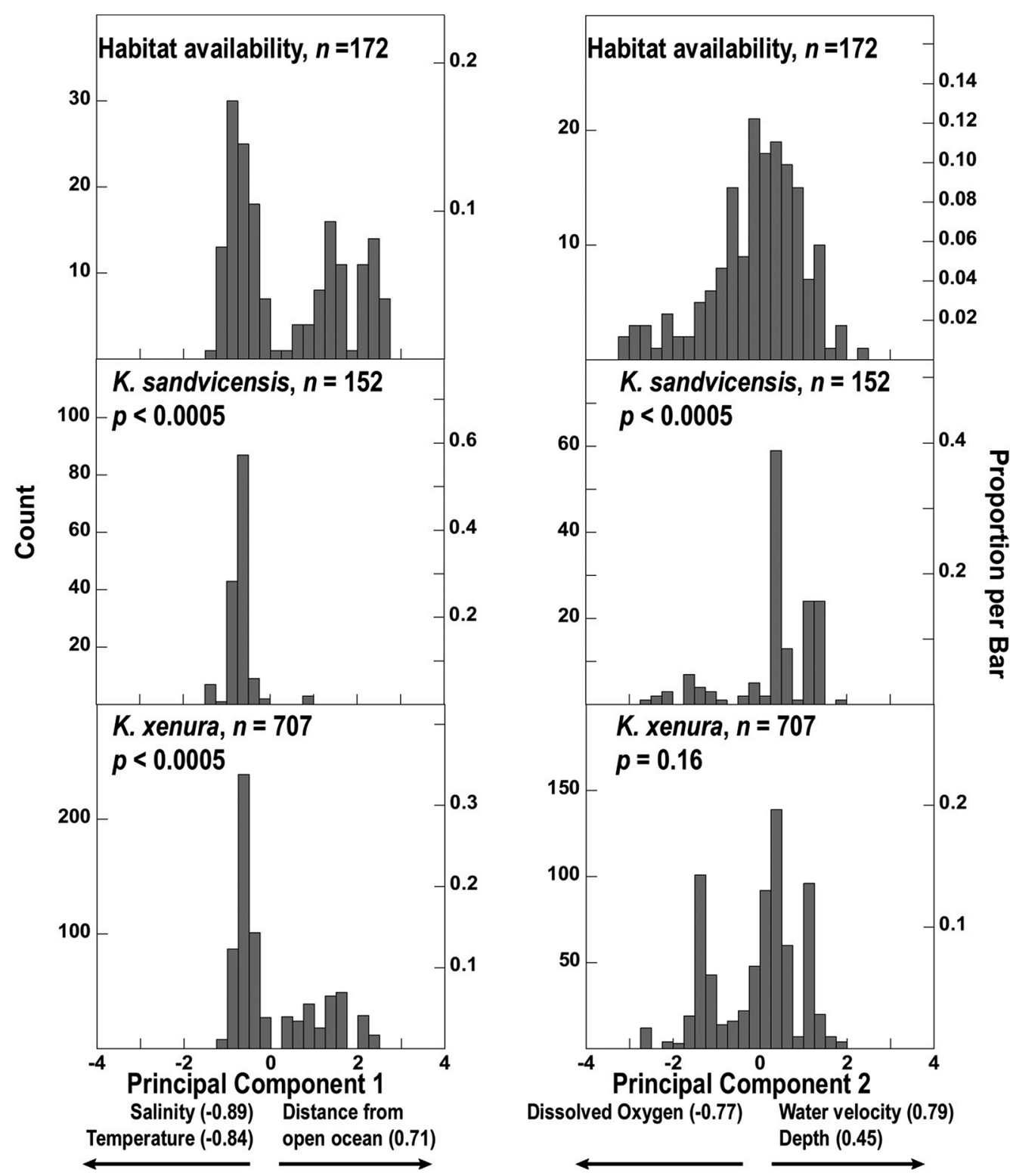

Figure 3. Tests of nonrandom microhabitat use for Principal Component Axes 1 and 2. Diagrams represent distributions of component scores for both microhabitat availability and species use data. Numbers in parentheses are component loading values for the variables represented by each axis. Microhabitat variables with loading values $\geq 0.40$ were included in the analysis. Two-sample Kolmogorov-Smirnoff tests were used to calculate $P$-values.

Indo-Pacific islands outside the Hawaiian archipelago where freshwater habitats are rare or nonexistent (e.g., Johnston Island [Randall and Randall 2001]). Kublia xenura is en- demic to the Hawaiian Islands (Randall and Randall 2001), where the presence of streams, rivers, and submarine freshwater springs (Street et al. 2007) result in an abundance of 
TABLE 3

Microhabitat Variable Means ( \pm Standard Error) for Juvenile Kublia Observed, with Mann-Whitney Test Statistic $(U)$ and Associated $P$-Values

\begin{tabular}{|c|c|c|c|c|}
\hline \multicolumn{2}{|c|}{ Variable } & \multirow{2}{*}{$\frac{\text { K. sandvicensis }}{(0)}$} & \multirow{2}{*}{$\begin{array}{c}\text { K. xепura } \\
(97)\end{array}$} & \multirow[t]{2}{*}{$U, P$-Value } \\
\hline (a) & Stream & & & \\
\hline & Temperature $\left({ }^{\circ} \mathrm{C}\right)$ & n.o. & $23.33 \pm 0.119$ & \\
\hline & Dissolved oxygen $\left(\mathrm{mg}\right.$ liter $\left.^{-1}\right)$ & n.o. & $9.16 \pm 0.074$ & \\
\hline & Salinity (ppt) & n.o. & $0.031 \pm 0.002$ & \\
\hline & Distance to open ocean (m) & n.o. & $401.48 \pm 50.41$ & \\
\hline & Mean water column velocity $\left(\mathrm{m} \mathrm{sec}^{-1}\right)$ & n.o. & $0.173 \pm 0.022$ & \\
\hline & Depth at fish $(\mathrm{cm})$ & n.o. & $46.41 \pm 3.07$ & \\
\hline \multirow[t]{7}{*}{ (b) } & Estuary & $(0)$ & $(92)$ & \\
\hline & Temperature $\left({ }^{\circ} \mathrm{C}\right)$ & n.o. & $22.87 \pm 0.068$ & \\
\hline & Dissolved oxygen $\left(\mathrm{mg}\right.$ liter $\left.{ }^{-1}\right)$ & n.o. & $9.36 \pm 0.030$ & \\
\hline & Salinity (ppt) & n.o. & $1.40 \pm 0.200$ & \\
\hline & Distance to open ocean (m) & n.o. & $8.21 \pm 35.98$ & \\
\hline & Mean water column velocity $\left(\mathrm{m} \mathrm{sec}^{-1}\right)$ & n.o. & $0.136 \pm 0.016$ & \\
\hline & Depth at fish $(\mathrm{cm})$ & n.o. & $71.93 \pm 2.21$ & \\
\hline \multirow[t]{7}{*}{ (c) } & Reef flat & $(59)$ & $(135)$ & \\
\hline & Temperature $\left({ }^{\circ} \mathrm{C}\right)$ & $26.80 \pm 0.086$ & $27.02 \pm 0.091$ & $3527.5, .08$ \\
\hline & Dissolved oxygen $\left(\mathrm{mg}\right.$ liter $\left.^{-1}\right)$ & $8.73 \pm 0.099$ & $8.86 \pm 0.083$ & $3463.5, .05$ \\
\hline & Salinity (ppt) & $33.51 \pm 0.186$ & $33.28 \pm 0.172$ & $4052.0, .77$ \\
\hline & Distance to open ocean (m) & $11.69 \pm 1.92$ & $13.17 \pm 1.28$ & $3495.5, .06$ \\
\hline & Mean water column velocity $\left(\mathrm{m} \mathrm{sec}^{-1}\right)$ & $0.111 \pm 0.005$ & $0.115 \pm 0.005$ & $4036.5, .84$ \\
\hline & Depth at fish $(\mathrm{cm})$ & $54.86 \pm 2.04$ & $51.60 \pm 1.45$ & $4427.5, .09$ \\
\hline \multirow[t]{7}{*}{ (d) } & Rocky shoreline & $(27)$ & $(101)$ & \\
\hline & Temperature $\left({ }^{\circ} \mathrm{C}\right)$ & $26.36 \pm 0.065$ & $23.75 \pm 0.119$ & $2668.5,<.0005$ \\
\hline & Dissolved oxygen $\left(\mathrm{mg}\right.$ liter $\left.^{-1}\right)$ & $7.29 \pm 0.124$ & $8.18 \pm 0.074$ & $328.5,<.0005$ \\
\hline & Salinity (ppt) & $33.72 \pm 0.712$ & $24.27 \pm 0.481$ & $2569.5,<.0005$ \\
\hline & Distance to open ocean (m) & $0.889 \pm 0.062$ & $43.13 \pm 5.04$ & $972.0, .02$ \\
\hline & Mean water column velocity $\left(\mathrm{m} \mathrm{sec}^{-1}\right)$ & $0.236 \pm 0.023$ & $0.243 \pm 0.018$ & $114.5, .16$ \\
\hline & Depth at fish $(\mathrm{cm})$ & $61.98 \pm 1.13$ & $43.49 \pm 2.01$ & $2064.0,<.0005$ \\
\hline \multirow[t]{7}{*}{ (e) } & Tide pool & $(66)$ & $(282)$ & \\
\hline & Temperature $\left({ }^{\circ} \mathrm{C}\right)$ & $26.99 \pm 0.209$ & $27.15 \pm 0.116$ & $8680.5, .39$ \\
\hline & Dissolved oxygen (mg liter ${ }^{-1}$ ) & $8.10 \pm 0.168$ & $8.68 \pm 0.064$ & $7051.0,<.0005$ \\
\hline & Salinity (ppt) & $30.00 \pm 0.860$ & $27.42 \pm 0.511$ & $10714.0, .01$ \\
\hline & Distance to open ocean (m) & $12.77 \pm 2.44$ & $10.27 \pm 0.382$ & $6969.5,<.0005$ \\
\hline & Mean water column velocity $\left(\mathrm{m} \mathrm{sec}^{-1}\right)$ & $0.201 \pm 0.023$ & $0.077 \pm 0.007$ & $13212.0,<.0005$ \\
\hline & Depth at fish $(\mathrm{cm})$ & $39.30 \pm 2.69$ & $41.19 \pm 0.945$ & $8783.0, .47$ \\
\hline \multirow[t]{7}{*}{ (f) } & Marine habitat types only & $(152)$ & $(518)$ & \\
\hline & Temperature $\left({ }^{\circ} \mathrm{C}\right)$ & $26.81 \pm 0.098$ & $26.45 \pm 0.091$ & $40903.5, .46$ \\
\hline & Dissolved oxygen (mg liter ${ }^{-1}$ ) & $8.20 \pm 0.094$ & $8.63 \pm 0.045$ & $28120.0,<.0005$ \\
\hline & Salinity (ppt) & $32.02 \pm 0.424$ & $28.42 \pm 0.323$ & $49201.0,<.0005$ \\
\hline & Distance to open ocean (m) & $10.24 \pm 1.34$ & $17.48 \pm 1.20$ & $28308.0,<.0005$ \\
\hline & Mean water column velocity $\left(\mathrm{m} \mathrm{sec}^{-1}\right)$ & $0.173 \pm 0.012$ & $0.120 \pm 0.006$ & $48013.0,<.0005$ \\
\hline & Depth at fish $(\mathrm{cm})$ & $49.37 \pm 1.60$ & $44.51 \pm 0.775$ & $48631.5,<.0005$ \\
\hline \multirow[t]{7}{*}{ (g) } & All habitat types combined & $(152)$ & $(707)$ & \\
\hline & Temperature $\left({ }^{\circ} \mathrm{C}\right)$ & $26.81 \pm 0.098$ & $25.56 \pm 0.089$ & $69103.5,<.0005$ \\
\hline & Dissolved oxygen $\left(\mathrm{mg}\right.$ liter $\left.^{-1}\right)$ & $8.20 \pm 0.094$ & $8.80 \pm 0.036$ & $32039.0,<.0005$ \\
\hline & Salinity (ppt) & $32.02 \pm 0.424$ & $21.01 \pm 0.520$ & $77929.0,<.0005$ \\
\hline & Distance to open ocean (m) & $10.24 \pm 1.34$ & $99.43 \pm 8.26$ & $28308.0,<.0005$ \\
\hline & Mean water column velocity $\left(\mathrm{m} \mathrm{sec}^{-1}\right)$ & $0.173 \pm 0.012$ & $0.129 \pm 0.006$ & $63859.5,<.0005$ \\
\hline & Depth at fish $(\mathrm{cm})$ & $49.37 \pm 1.60$ & $48.34 \pm 0.839$ & $58655.0, .08$ \\
\hline \multirow[t]{7}{*}{ (h) } & Availability measurements: All habitat types combined & \multicolumn{2}{|c|}{$(172)$} & \\
\hline & Temperature $\left({ }^{\circ} \mathrm{C}\right)$ & \multicolumn{2}{|c|}{$24.61 \pm 0.191$} & \\
\hline & Dissolved oxygen $\left(\mathrm{mg}\right.$ liter $\left.{ }^{-1}\right)$ & \multicolumn{2}{|c|}{$9.02 \pm .095$} & \\
\hline & Salinity (ppt) & \multicolumn{2}{|c|}{$18.86 \pm 1.13$} & \\
\hline & Distance to open ocean (m) & \multicolumn{2}{|c|}{$207.71 \pm 26.09$} & \\
\hline & Mean water column velocity $\left(\mathrm{m} \mathrm{sec}^{-1}\right)$ & \multicolumn{2}{|c|}{$0.234 \pm .020$} & \\
\hline & Depth at fish $(\mathrm{cm})$ & \multicolumn{2}{|c|}{$41.36 \pm 2.82$} & \\
\hline
\end{tabular}

Note: Numbers in parentheses indicate sample size; n.o., not observed. No K. sandvicensis were observed in streams and estuaries, therefore Mann-Whitney test statistics could not be calculated for data collected in those habitat types. 
low-salinity habitats. The theory of limiting similarity (MacArthur and Levins 1967) predicts that between two competing species, a maximum amount of overlap in ecological niche space exists, above which one species will be excluded (Abrams 1983). The ability of K. sandvicensis and K. xenura to coexist in the Hawaiian Islands despite being closely related and morphologically similar is likely facilitated by marked differences in their spatial ecology as juveniles.

Juvenile $K$. sandvicensis have distinct morphological adaptations that may facilitate survival in high-energy surge zones. Kublia sandvicensis is less deep-bodied than $K$. xenura (McRae 2007), resulting in a more hydrodynamically efficient profile that may enhance their ability to maintain their position in high water velocity areas. The pattern of dark vermiculated lines present along the dorsal and upper lateral surfaces of juvenile $K$. sandvicensis (Figure 1) provides camouflage in turbulent, foamy waters (authors, pers. obs.) and may help them avoid marine predators.

It is important to emphasize that before Randall and Randall's (2001) reclassification of the kuhliids of the central Pacific, only one species, identified as $K$. sandvicensis, was believed to exist in the Hawaiian Islands. Previous descriptions of the habitats used by $K$. sandvicensis in the Hawaiian Islands (e.g., Tester and Takata 1953, Tinker 1978, Hoover 1993, Randall 1996, Yamamoto and Tagawa 2000), therefore, could have referred to either K. sandvicensis, K. xenura, or (most likely) both species. All of these descriptions state that $K$. sandvicensis inhabits freshwater, estuarine, and marine habitats, a pattern that has now been documented for $K$. xenura. The species now identified as $K$. sandvicensis has been shown in this study to utilize a much narrower range of habitats than $K$. xenura during their juvenile stage, a fact that may require unique management strategies to effectively conserve this species.

Many questions regarding the ecology of kuhliid fishes in Hawai' $i$ remain to be addressed in future studies. For example, are observed differences in the habitats used by juvenile $K$. sandvicensis and $K$. xenura due to physiological limitations leading to differences in salinity tolerance? Are juvenile $K$. sandvicensis and $K$. xenura utilizing similar food resources in habitats where they co-occur? Beck et al. (2001) defined nursery habitats as subsets of juvenile habitats that make a greater than average contribution to the adult population. Future investigations that focus on identifying which of the juvenile habitats outlined here represent true nurseries for Hawaiian kuhliids will provide fisheries managers in Hawai' $i$ with ecological information that will enhance their ability to effectively manage these important indigenous fishes.

\section{ACKNOWLEDGMENTS}

We thank the Hawai'i Division of Aquatic Resources for their logistical and financial support of this project. Funding was also provided by the University of Tampa's Dana Grant program. Danielle Giordenella provided assistance with data entry. Robert $T$. Nishimoto provided a thorough review of the manuscript for which we are thankful.

\section{Literature Cited}

Abrams, P. 1983. The theory of limiting similarity. Annu. Rev. Ecol. Syst. 14:359-376.

Beck, M. W., K. L. Heck Jr., K. W. Able, D. L. Childers, D. B. Eggleston, B. M. Gillanders, B. Halpern, C. G. Hays, K. Hoshino, T. J. Minello, R. J. Orth, P. F. Sheridan, and M. P. Weinstein. 2001. The identification, conservation, and management of estuarine and marine nurseries for fish and invertebrates. BioScience 51:633641.

Benson, L. K., and J. M. Fitzsimons. 2002. Life history of the Hawaiian fish Kublia sandvicensis as inferred from daily growth rings of otoliths. Environ. Biol. Fishes 65:131-137.

Desmond, J. S., J. B. Zedler, and G. D. Williams. 2000. Fish use of tidal creek habitats in two southern California salt marshes. Ecol. Eng. 14:233-252.

Gosline, W. A. 1965. Vertical zonation of inshore fishes in the upper water layers of the Hawaiian Islands. Ecology 46:823-831. 
Gosline, W. A., and V. E. Brock. 1965. Handbook of Hawaiian fishes. 2nd ed. University of Hawai'i Press, Honolulu.

Grossman, G. D., and M. C. Freeman. 1987. Microhabitat use in a stream fish assemblage. J. Zool. 212:151-176.

Hendon, J. R., M. S. Peterson, and B. H. Comyns. 2001. Seasonal distribution of gobiids in waters adjacent to estuarine marsh-edge habitats: Assessing the effects of habitat alteration. Proc. Gulf Caribb. Fish. Inst. 52:428-441.

Hoover, J. P. 1993. Hawaii's fishes: A guide for snorkelers and divers and aquarists. Mutual Publishing, Honolulu, Hawai'i.

Hosaka, E. Y. 1973. Shore fishing in Hawai'i. The Petroglyph Press, Hilo, Hawai'i.

Jennings, S. 1992. Potential effects of estuarine development on the success of management strategies for the British bass fishery. Ambio 21:468-470.

MacArthur, R., and R. Levins. 1967. The limiting similarity, convergence, and divergence of coexisting species. Am. Nat. 101:377-385.

McRae, L. B. 2007. Morphometric and genetic confirmation of two species of Kublia (Osteichthyes: Kuhliidae) in Hawai'i. Pages 113-123 in N. L. Evenhuis and J. M. Fitzsimons, eds. Biology of Hawaiian streams and estuaries. Bishop Mus. Bull. Cult. Environ. Stud. 3.

Randall, J. E. 1985. Guide to Hawaiian reef fishes. Harrowood Books, Newtown Square, Pennsylvania.

- 1996. Shore fishes of Hawai'i. Natural World Press, Vida, Oregon.

Randall, J. E., and H. A. Randall. 2001. Review of the fishes of the genus Kublia (Per- ciformes: Kuhliidae) of the central Pacific. Pac. Sci. 55:227-256.

Rozas, L. P., and C. T. Hackney. 1983. The importance of oligohaline estuarine wetland habitats to fisheries resources. Wetlands 3:77-89.

SPSS Inc. 1998. SYSTAT 8.0. SPSS Inc., Chicago.

Street, J. H., K. L. Knee, E. E. Grossman, and A. Paytan. 2007. Submarine groundwater discharge and nutrient addition to the coastal zone and coral reefs of leeward $\mathrm{Ha}-$ waii. Mar. Chem. 109:355-376.

Tester, A. L., and M. Takata. 1952. First quarterly report on the biology of the āholehole, a potential baitfish. Industrial Research Advisory Council Project No. 29, 1953. Hawai'i Marine Laboratory. 1953. A contribution to the biology of the āholehole, a potential baitfish. Industrial Research Advisory Council Grant no. 29, 1953. Hawai'i Marine Laboratory.

Tinker, S. W. 1978. Fishes of Hawai'i. Hawaiian Service, Honolulu, Hawai'i.

Titcomb, M. 1972. Native use of fish in Hawai'i. The University Press of Hawai'i, Honolulu.

Whitfield, A. K. 1997. Fish conservation in South African estuaries. Aquat. Conserv. 7:1-11.

Witte, A., and C. Mahaney. 1998. Hawaiian reef fish. Island Heritage Publishing, 'Aiea, Hawai'i.

Yamamoto, M. N., and A. W. Tagawa. 2000. Hawaii's native and exotic freshwater animals. Mutual Publishing, Honolulu, Hawai'i. 